\title{
GENETICAL AND DEVELOPMENTAL STUDIES ON THE "Ph" AGGLUTINOGEN IN THE CHICKEN RED CELLS
}

\author{
YOSHIHISA FUJIO $^{1 / *}$ AND MAKOTO MIZUTANI ${ }^{2)}$ \\ Laboratory of Animal Genetics, Faculty of Agriculture, Nagoya University \\ and ${ }^{2}$ NIBS Laboratory Animal Research Station, Nagoya 644
}

Received May 29, 1975

The extracts from Pisum sativum seeds (PHA) are capable of agglutinating red cells obtained from only egg-laying females in the chicken, but in these egg-laying females some are responsive to agglutination and others fail to be agglutinated. The restriction of red cell agglutinability to egg-laying females is due to the activity of estrogen in egg-laying females which may stimulate the production of the " $\mathrm{Ph}$ " agglutinogen. This is based on the result of the correlation between the egg production and the red cell agglutinability. The agglutinability become stronger or weaker as the egg production rises and falls. The occurrence of the agglutinogen designated " $\mathrm{Ph}$ " is restricted to the red cells from egg-laying females of certain strains and the data on the cross of agglutinable strain (BM-C) with non-agglutinable strain (WL-M) suggest that the appearance of " $\mathrm{Ph}$ " agglutinogen is dependent on genotype as well as hormone (Mizutani and Fujio 1971).

Scheinberg and Reckel (1962) reported on the effects of estrogen and genotype on the production of the "Hi" agglutinogen responsive to the extracts from Lathyrus cicera and Pisum arvense seeds. Salminen $(1959,1962)$ found that the tick borne encephalitis virus agglutinated red cells from mature male chickens but did not agglutinate those from mature female chickens and that the red cell agglutinability in males was suppressed immediately by an injection of estrogen. Similar phenomenon was found in Japanese quail whose red cells were agglutinated by the extracts from Glycine max seeds (Mizutani et al. 1973).

In this paper, it is shown that the " $\mathrm{Ph}$ " agglutinogen was produced in red cells from a certain genotype with an action of estrogen and that the appearance of the agglutinogen was age-dependent.

\section{MATERIALS AND METHODS}

The seed extracts (PHA) were obtained as follows: the seeds of Pisum sativum were soaked in phosphate buffered saline (PBS) and homogenized in equal volume of PBS by a homobrender. The homogenates were passed through a coase filter to remove debris. The juice was heated at $60^{\circ} \mathrm{C}$ for 30 minutes and centrifuged at $10,000 \mathrm{rpm}$ for

1) Present address: Department of Fishery Science, Faculty of Agriculture, Tohoku University, Sendai 980. 
30 minutes to obtain clear supernatants. The agglutination test and scoring were performed by the same procedures as those in the previous report (Mizutani and Fujio 1971).

The inbred strains of chickens, Black Minorca C (BM-C) and White Leghorn M (WL-M) were used in the present work. The former is a strain whose red cells are agglutinable and the latter is a strain whose red cells are not agglutinable. Some chicks were given an injection of diethylstilbestrol $(10.0 \mathrm{mg})$ intramuscularly.

\section{RESULTS}

1. Differential appearance of the "Ph" agglutinogen in different ages and sexes.

The result of tests for the agglutinability of red cells from egg-laying females is shown in Table 1. Red cells from all BM-C egg-laying female chickens were agglutinated but those from all WL-M egg-laying female chickens were not agglutinated. On the other hand, the result of tests for the agglutinability of red cells from mature non-laying females and males showed that red cells from both strains failed to be agglutinated. The red cells from 10 week old chickens were not agglutinated regardless of sex and strain. In these two inbred strains tested through more than 5 generations, there was no segregation of chickens on the basis of the agglutinability of their red cells to PHA in the egg laying state. In the crosses between BM-C and WL-M, all $F_{1}$ female progenies showed the presence of agglutinogen in their red cells in the egg laying state. This fact suggests that the agglutinability appears to be hereditable

Table 1. Differential appearance of the "Ph" agglutinogen in red cells from chickens of different ages and sexes

\begin{tabular}{|c|c|c|c|c|}
\hline \multirow{2}{*}{ Strain } & \multirow{2}{*}{ Sex and age } & \multirow{2}{*}{$\begin{array}{l}\text { No. of } \\
\text { chickens } \\
\text { tested }\end{array}$} & \multicolumn{2}{|c|}{ Response of red cells to PHA } \\
\hline & & & Agglutinable & Non-agglutinable \\
\hline \multirow[t]{5}{*}{$\mathrm{BM}-\mathrm{C}$} & male (10-week) & 10 & 0 & 10 \\
\hline & female $(10$-week $)$ & 10 & 0 & 10 \\
\hline & male (adult) & 21 & 0 & 21 \\
\hline & female (laying) & 43 & 43 & 0 \\
\hline & female (non-laying) & 15 & 0 & 15 \\
\hline \multirow[t]{5}{*}{ WL-M } & male (10-week) & 10 & 0 & 10 \\
\hline & female (10-week) & 10 & 0 & 10 \\
\hline & male (adult) & 19 & 0 & 19 \\
\hline & female (laying) & 37 & 0 & 37 \\
\hline & female (non-laying) & 12 & 0 & 12 \\
\hline \multirow[t]{5}{*}{$(\mathrm{WL}-\mathrm{M} \times \mathrm{BM}-\mathrm{C}) \mathrm{F}_{1}$} & male (10-week) & 10 & 0 & 10 \\
\hline & female (10-week) & 12 & 0 & 12 \\
\hline & male (adult) & 4 & 0 & 4 \\
\hline & female (laying) & 12 & 12 & 0 \\
\hline & female (non-laying) & 5 & 0 & 5 \\
\hline
\end{tabular}




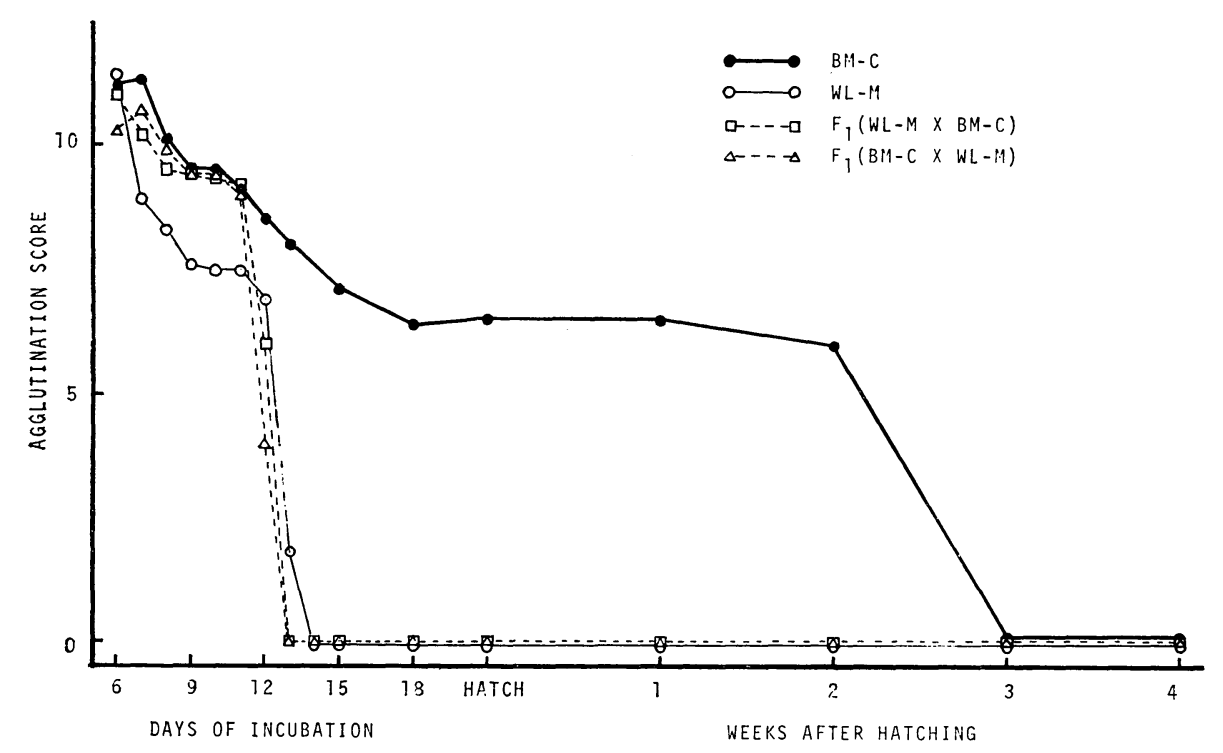

Fig. 1. Age-dependent changes in agglutination scrores of " $\mathrm{Ph}$ " agglutinogen in red cells from the BM-C, WL-M, and their hybrid strains.

by a dominant gene.

To test whether red cells from embryos of these strains are agglutinated with seed extracts or not, red cells were obtained from the BM-C, WL-M, and their hybrid embryos at various developmental stages. The results are shown in Fig. 1. It is indicated that red cells from embryos before 11th day in their development were agglutinable regardless of sex and strain. The agglutination score showed a high level in 6th day embryos in all strains, decreased with development of embryos, and reached to zero in the BM-C, WL-M, and their hybrids, at the stages of 3 week old chicks, 14th day embryos, and 13th day embryos, respectively. Thus, the agglutinability of red cells from the WL-M and $F_{1}$ hybrid was lost earlier than that from the BM-C. From the curves of decreasing agglutinability, it was indicated that with regard to the agglutinability of red cells the $\mathrm{F}_{1}$ hybrids were similar to the BM-C strain at the stage of 6-12th day embryos and were similar to the WL-M strain after the stage of 13 th day embryos.

Since the time of reappearance of agglutinogen was restricted to the egg-laying females in the BM-C strain, it seemed that the production of agglutinogen might be associated with female sexual maturity, that is, the egg production. Red cells from mature females were tested for their agglutinability at various times before and after the first egg production (Fig. 2). The agglutinability was not found before the onset of egg laying in both BM-C and WL-M strains. In the BM-C strain, the agglutinability appeared within 1 week after the onset of egg laying but not in the WL-M strain. When the agglutinability of red cells and the egg production in percent in egg-laying females were recorded weekly, an intimate correlation was found between these two properties, that is, the agglutination become stronger or weaker as the egg production 


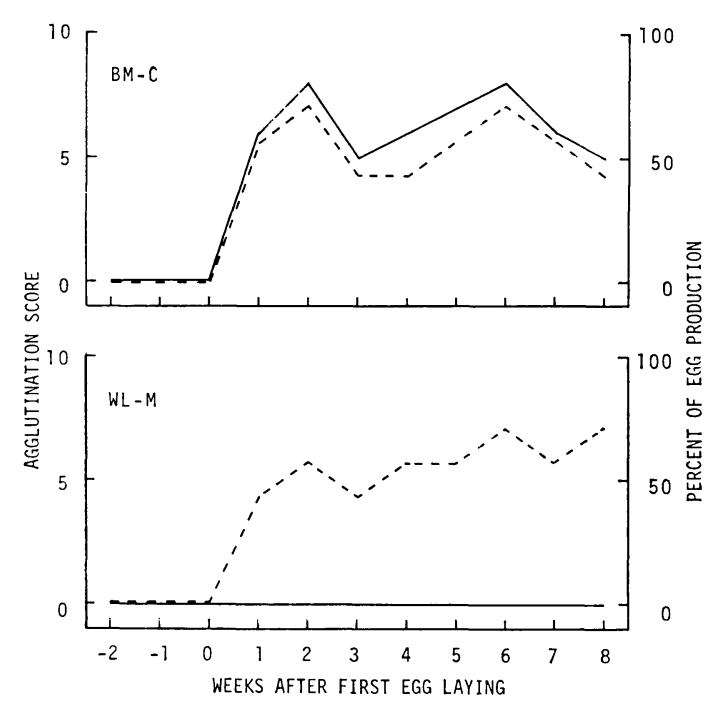

Fig. 2. The relationship between the cumulative egg production and the agglutinability of red cells in the BM-C and WL-M strains. Solid line: agglutination; Broken line: egg production.

rises and falls. This fact suggests that the production of " $\mathrm{Ph}$ " agglutinogen is affected by two factors, the genotype and the egg production.

\section{Genetic analysis}

To elucidate the mode of inheritance of the production of agglutinogen in red cells, $\mathrm{BM}-\mathrm{C}$ chickens were crossed to WL-M chickens. In the egg laying state all $\mathrm{F}_{1}$ female progenies showed the presence of agglutinogen in their red cells, and $F_{2}$ female progenies were classified into two groups, 24 females which had agglutinogen and 10 females which had no agglutinogen in their red cells (Table 2). The ratio between the numbers in these two groups was 2.4:1.0 which corresponded significantly to $3: 1$ in Mendelian ratio $(\mathrm{P}>0.5)$. This indicates that the inheritance of agglutinogen in red cells was controlled by a single dominant gene. This gene was not sex-linked from the data on the reciprocal crosses of the BM-C and WL-M strains. However, the action of this gene was expressed in red cells from egg-laying females since red cells from early embryos were not dependent on this gene. It is suggested that the red cell agglutinability may be controlled by another structure gene and the gene described above may be a regulatory gene and the function of the latter starts about 11th day of incubation.

Furthermore, the cross experiment was performed to examine the red cell agglutinability from 18th day embryos. The results showed that red cells from agglutinable strain (BM-C) were agglutinated but those from non-agglutinable strain (WL-M) were not regardless of sex. All $\mathrm{F}_{1}$ progenies from the reciprocal crosses showed the absence 
Table 2. Segregation of the " $\mathrm{Ph}$ " agglutinogen in adult $\mathrm{F}_{2}$ progenies from the cross, $\mathrm{BM}-\mathrm{C} \times \mathrm{WL}-\mathrm{M}$

\begin{tabular}{|c|c|c|c|c|}
\hline \multirow{2}{*}{ Strain } & \multirow{2}{*}{ Sex } & \multirow{2}{*}{$\begin{array}{l}\text { No. of } \\
\text { chickens } \\
\text { tested }\end{array}$} & \multicolumn{2}{|c|}{ Response of red cells of PHA } \\
\hline & & & Agglutinable & Non-agglutinable \\
\hline \multirow[t]{2}{*}{$\mathrm{BM}-\mathrm{C}$} & male & 21 & 0 & 21 \\
\hline & female & 43 & 43 & 0 \\
\hline \multirow[t]{2}{*}{ WL-M } & male & 19 & 0 & 19 \\
\hline & female & 37 & 0 & 37 \\
\hline \multirow[t]{2}{*}{$(\mathrm{WL}-\mathrm{M} \times \mathrm{BM}-\mathrm{C}) \mathrm{F}_{1}$} & male & 4 & 0 & 4 \\
\hline & female & 12 & 12 & 0 \\
\hline \multirow[t]{2}{*}{$(\mathrm{BM}-\mathrm{C} \times \mathrm{WL}-\mathrm{M}) \mathrm{F}_{1}$} & male & 3 & 0 & 3 \\
\hline & female & 5 & 5 & 0 \\
\hline \multirow[t]{2}{*}{$(\mathrm{WL}-\mathrm{M} \times \mathrm{BM}-\mathrm{C}) \mathrm{F}_{2}$} & male & 9 & 0 & 9 \\
\hline & female & 34 & 24 & 10 \\
\hline
\end{tabular}

* All female birds were egg-laying.

Supposed that the segregation in $\mathrm{F}_{2}$ progenies would be $3: 1, \chi^{2}=0.3529, \mathrm{D} . \mathrm{F} .=1, \mathrm{P}>0.50$.

Table 3. Segregation of the "Ph" agglutinogen in 18-day embryonic $\mathrm{F}_{2}$ progenies from the cross, $\mathrm{BM}-\mathrm{C} \times \mathrm{WL}-\mathrm{M}$

\begin{tabular}{lccc}
\hline \multirow{2}{*}{ Strain } & $\begin{array}{c}\text { No. of } \\
\text { embryos } \\
\text { tested }\end{array}$ & \multicolumn{2}{c}{ Response of red cells to PHA } \\
\cline { 3 - 4 } & 10 & Agglutinable & Non-agglutinable \\
\hline BM-C & 10 & 10 & 0 \\
WL-M & 10 & 0 & 10 \\
$(\mathrm{WL}-\mathrm{M} \times \mathrm{BM}-\mathrm{C}) \mathrm{F}_{1}$ & 10 & 0 & 10 \\
$(\mathrm{BM}-\mathrm{C} \times \mathrm{WL}-\mathrm{M}) \mathrm{F}_{1}$ & 127 & 34 & 10 \\
$(\mathrm{WL}-\mathrm{M} \times \mathrm{BM}-\mathrm{C}) \mathrm{F}_{2}$ & & & 93 \\
\hline
\end{tabular}

Supposed that the segregation in $\mathrm{F}_{2}$ progenies would be $1: 3, \chi^{2}=0.2064$, D.F. $=1, \mathrm{P}>0.50$.

of agglutinogen in their red cells and the $F_{2}$ progenies were classified into two groups, 34 embryos which had agglutinogen and 93 embryos which had no agglutinogen in their red cells (Table 3 ). The ratio between the numbers in these two groups corresponded significantly to $1: 3$ in Mendelian ratio $(\mathrm{P}>0.5)$, The result was different from that obtained in egg-laying females. The difference is caused by the difference in phenotypic expression of the red cell agglutinability between egg-laying females and 18 th day embryos in heterozygous individuals.

\section{Effects of injection of diethylstilbestrol in several immature chicks}

The correlation between the agglutinability and the egg production suggests that injection of estrogen into sexually immature chicks of either sex would be effective in the appearance of agglutinability in their red cells. Diethylstibestrol was injected into 5,10 , and 20 week chicks to determine whether the estrogen is effective in the transformation of the red cells to become agglutinable. The results are presented in Table 


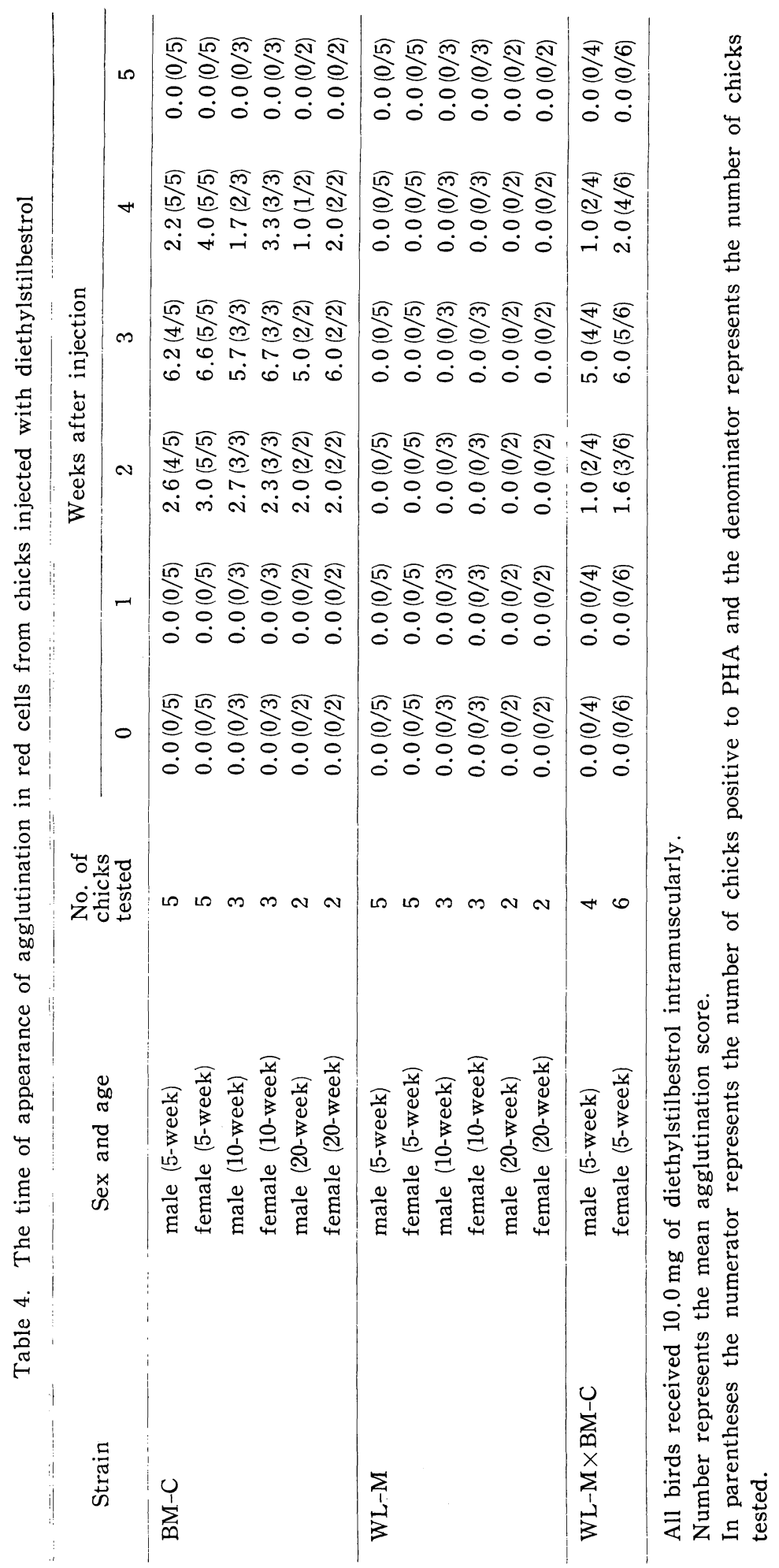


Table 5. Segregation of the estrogen-stimulated " $\mathrm{Ph}$ " aggultinogen in 5-week $\mathrm{F}_{2}$ prognies from the cross, $\mathrm{BM}-\mathrm{C} \times \mathrm{WL}-\mathrm{M}$

\begin{tabular}{|c|c|c|c|c|}
\hline \multirow{2}{*}{ Strain } & \multirow{2}{*}{ Sex } & \multirow{2}{*}{$\begin{array}{l}\text { No. of } \\
\text { chicks } \\
\text { tested }\end{array}$} & \multicolumn{2}{|c|}{ Response of red cells to PHA } \\
\hline & & & Agglutinable & Non-agglutinable \\
\hline \multirow[t]{2}{*}{$\mathrm{BM}-\mathrm{C}$} & male & 5 & 5 & 0 \\
\hline & female & 5 & 5 & 0 \\
\hline \multirow[t]{2}{*}{ WL-M } & male & 5 & 0 & 5 \\
\hline & female & 5 & 0 & 5 \\
\hline \multirow[t]{2}{*}{$(\mathrm{WL}-\mathrm{M} \times \mathrm{BM}-\mathrm{C}) \mathrm{F}_{1}$} & male & 4 & 4 & 0 \\
\hline & female & 6 & 6 & 0 \\
\hline \multirow[t]{2}{*}{$(\mathrm{BM}-\mathrm{C} \times \mathrm{WL}-\mathrm{M}) \mathrm{F}_{1}$} & male & 4 & 4 & 0 \\
\hline & female & 4 & 4 & 0 \\
\hline \multirow[t]{2}{*}{$(\mathrm{WL}-\mathrm{M} \times \mathrm{BM}-\mathrm{C}) \mathrm{F}_{2}$} & male & 58 & 43 & 15 \\
\hline & female & 54 & 38 & 16 \\
\hline
\end{tabular}

Supposed that segragation of $\mathrm{F}_{2}$ male and female progenies would be $3: 1, \chi^{2}=0.4286$, D.F. $=1$, $\mathrm{P}>0.50$.

4. All chicks of the BM-C strain showed the appearance of agglutinability in their red cells 2 weeks after injection and then the agglutination scores rose up to a high level as the time proceeded regardless of sex and ages. After 3 weeks following injection, the red cells exhibited the maximum score of agglutinability, then decreased during another one week and reached to zero 5 weeks after injection. The time required to achieve the maximum level of agglutinability was 3 weeks. On the other hand, all chicks of the WL-M strain showed no agglutinability regardless of sex and ages. Although chicks of the $\mathrm{F}_{1}$ hybrids showed lower agglutination score than those of the BM-C strain, they were agglutinable. These results suggest that the production of "Ph" agglutinogen began after injection of estrogen and that the genotype of recipient chicks is essential for the responsiveness to estrogen. It was also interesting that the agglutinability is expressed phenotypically in male genotype by the injection of estrogen.

The agglutinability of red cells in the $\mathrm{F}_{2}$ progenies was examined in 5 week young chicks by injection of diethylstilbestrol as shown in Table 5 . The $F_{2}$ female and male progenies were classified into two groups by their red cell agglutinability. In female chicks 38 had agglutinogen and 16 had no agglutinogen, and in male chicks 43 had agglutinogen and 15 had no agglutinogen. The ratios between agglutinable and nonagglutinable chicks in these two groups corresponded significantly to $3: 1$ in Mendelian ratio. The results coincided with those obtained in egg-laying females.

\section{DISCUSSION}

The "Ph" agglutinogen in chicken red cells was detected by using a PHA obtained from the seed extract of Pisum sativum. The "Ph" agglutinogen was detected only in egg-laying females but not in non-laying females and males, and its appearance was associated with the egg production as shown in the previous report (Mizutani and 
Fujio 1971). The injection of diethylstilbestrol revealed that estrogen level was essential for the production of "Ph" agglutinogen. The lag between the injection of estrogen and the appearance of agglutinability may be explained by assuming that the agglutinogen is produced initially in newly formed red cell stem cells in the bone marrow and that such cells are substituted for the non-agglutinable red cells. Cross experiments between the agglutinable strain and non-agglutinable strain showed that the presence of "Ph" agglutinogen was regulated by a single autosomal gene. From the pattern of the agglutinability of red cells with $\mathrm{PHA}$, the "Ph" agglutinogen seems to be identical to the "Hi" agglutinogen reported by Scheinberg and Reckel (1961a, b, 1962).

In the present study evidence presented that red cells obtained from early embryos were all agglutinable regardless sex and genotype. The previous report indicated that the same agglutinogen was present in red cells obtained from embyos and egg-laying females (Mizutani and Fujio 1971). Salminen $(1959,1962)$ reported that the tick borne encephalitis virus agglutinated red cells from mature males but not those from mature females and that such agglutinogen was detected in red cells from newly hatched chicks regardless of sex. In the present work it is interesting that in both agglutinable and nonagglutinable strains red cells obtained from embryos were agglutinable. The agglutination score showed high levels in red cells from 6th day embryos and decreased with the development of embryos. The red cells from the BM-C, WL-M, and their hybris strains lost their agglutinability 3 weeks after hatching, 14 days of incubation, and 13 days of incubation, respectively. The $F_{1}$ hybrids in the reciprocal crosses showed similar decreasing curves of agglutinability to that of the WL-M strain. This fact indicates that the agglutinability was not affected maternally by the cytoplasm from WL-M hens.

Scheinberg and Reckel (1962) reported that the production of "Hi" agglutinogen was affected by the genotype and an extrinsic factor (estrogen). Our experiments showed the same result as that of their experiments. The question still remains unanswered how the above interpretation is adapted to explain the fact that red cells from embryos were agglutinable regardless of genotype of their parents. It was reported by several workers that chicken egg yolk contained estrogenic compounds (Altman and Hutt 1938; Marlow and Richert 1940). Thus, it is interpreted that the production of agglutinogen in embryonic red cells may be associated with estrogen contained in yolk.

However, it was not interpreted why red cells of embryos were agglutinable in the presence of yolk estrogen in the non-agglutinable strain (WL-M). It seems that the production of " $\mathrm{Ph}$ " agglutinogen may fit to an operon theory. In other words, the production of agglutinogen induced by estrogen may be controlled by a regulatory gene but not by a structure gene and the function of the gene starts from about 11 days of incubation and produce an inhibitor which repress the responsiveness of red cells to the estrogen stimulation. The evidence for the existence of the inhibitor is based on the result of earlier loss of agglutinability in the WL-M and $F_{1}$ hybrid embryos than in the BM-C embryos and also no transformation of red cells following the injection of estrogen in the non-agglutinable strain before chickens reach to their sexual maturity. The difference in phenotypic expression of the agglutinability of red cells in the heterozygous condition between egg-laying females and 18th day embryos suggests that there may be an antagonistic competition between the actions of the inhibitor and 
estrogen. The lower agglutinability of heterozygous embryonic red cells might be caused by the production of larger amount of the inhibitor than that of heterozygous egg-laying females.

\section{SUMMARY}

The "Ph" agglutinogen was detected in red cells from egg-laying females but not in those from mature males in the BM-C strain. In the tests for the agglutinability of red cells in egg-laying females, the agglutinable strain (BM-C) and the non-agglutinable strain (WL-M) were found. In regard to the agglutinability of embryonic red cells, "Ph" agglutinogen was found in red cells from all embryos tested regardless of sex and strain and it was lost with development of embryos.

Injection experiment of diethylstilbestrol revealed that the estrogen level was essential for the production of agglutinogen. Genetic analysis showed that the production of agglutinogen was controlled by a single autosomal gene. These results indicate the participation of both estrogen and genotype in the production of " $\mathrm{Ph}$ " agglutinogen in chick red cells.

\section{ACKNOWLEDGMENT}

The authors wish to express their hearty thanks to Prof. K. Kondo for his advice and encouragement. The authors also thanks to Dr. Y. Kuroda of the National Institute of Genetics for reading the manuscript and offering his valuable suggestions. This work was supported by a grant (911207) from the Research Fund of Ministry of Education of Japan.

\section{LITERATURE CITED}

Altmann, M., and F. B. Hutt, 1938 The influence of estrogens in egg yolk upon avian blood calcium. Endocrinology 23: 793-799.

Marlow, H. W., and D. Richert, 1940 Estrogens of the fowl. Endocrinology 26: 531-534.

Mizutani, M., and Y. Fujio, 1971 Developmental appearance of the chiken red cell agglutinogen detected with phytohemagglutinin. Japan. J. Zootech. Sci. 42: 401-408.

Mizutani, M., H. Umezawa, S. Kuramasu, and Y. Tazima, 1973 Blood grouping of experimental animals by phytohemagglutinin. ABRI 2: 5-7.

Salminen, A., 1959 Difference in the agglutinability of rooster and hen erythrocytes by the tick borne encephalitis virus. Ann. Med. Exp. Biol. Fenniae (Helsinki) 37: 400-406.

Salminen, A., 1962 Effect of estrogenic hormones on agglutinability of chiken erythrocytes by arthropod-borne viruses. Nature 194: 1301-1302.

Scheinberg, S. L., and R. P. Reckel, 1961a Detection of red cell agglutinogens with lectin in chickens. Poultry Sci. 40: 689-698.

Scheinberg, S. L., and R. P. Reckel, 1961b Somatic variation of red cell agglutinogens due to hormonal influence. Poultry Sci. 40: 795-807.

Scheinberg, S. L., and R. P. Reckel, 1962 Studies of the "Hi" agglutinogen in chicken. Ann. New York Acad. Sci. 97: 194-204. 